\author{
PAWEŁ SUT \\ ORCID: 0000-0003-4623-207X \\ Uniwersytet Gdański
}

\title{
KILKA UWAG O ZWIĄZKACH WSPÓŁCZESNEJ INTYMNOŚCI, PRAWA I POLITYCZNOŚCI (PRZECIWKO HEGEMONICZNEMU DYSKURSOWI PRAWOZNAWSTWA DOTYCZACEEMU ART. 18 KONSTYTUCJI RP Z 1997 ROKU)
}

\begin{abstract}
Abstrakt: Prawne rozstrzygnięcia dokonywane na podstawie interpretacji art. 18 Konstytucji RP, zgodnie z którą przepis ten nie tylko uniemożliwia instytucjonalizację na poziomie ustawowym w Polsce związków jednopłciowych, lecz także uniemożliwia zarejestrowanie w Polsce małżeństwa zawartego za granicą przez osoby tej samej płci, a nawet że przepis ten stanowi jedną z przeszkód transkrypcji zagranicznego aktu urodzenia dziecka, w którym jako rodzice wpisane są osoby tej samej płci, prowadzą do opresji. Inspiruje to do krytycznego spojrzenia na ten hegemoniczny dyskurs prawoznawstwa dotyczący art. 18 Konstytucji, a także do postulatu kreowania przez prawoznawstwo i orzecznictwo sądowe alternatywnych dyskursów w tym zakresie — uwzględniających rzeczywistą, a nie minimalistyczną lub formalną realizację wolności i równości — które w przyszłości mogłyby przejąć pozycję hegemoniczną. W opracowaniu zawarte jest nawiązanie do idei Chantal Mouffe, że zadaniem demokracji jest przekształcanie relacji antagonistycznych (relacji my-oni, których strony są wrogami niemającymi wspólnych punktów odniesienia) w relacje agoniczne (relacje my-oni, których strony są dla siebie nie wrogami, lecz „przeciwnikami”). Bez wątpienia współcześnie w Polsce konfrontacja pomiędzy środowiskami konserwatywnymi a osobami LGBT i ich sojusznikami nie ma charakteru agonicznego i wątpliwe jest, w aktualnych warunkach politycznych, przeniesienie tego antagonizmu do agonicznej, publicznej sfery sporu. Zdaniem autora pewną rolę do odegrania ma tu jednak prawoznawstwo (i orzecznictwo sądowe), które powinno wykonać wysiłek mający na celu skonfrontowanie różnych prawniczych dyskursów na temat praw osób LGBT. Ewentualna utrata pozycji hegemonicznej przez aktualnie w Polsce dominujący dyskurs prawniczy (dotyczący art. 18 Konstytucji RP) mogłaby w przyszłości doprowadzić do „ucywilizowania” publicznej konfrontacji dyskursów dotyczących roszczeń osób LGBT (i być może przekształcenia rejestrowanej obecnie relacji antagonistycznej łączącej konserwatystów z osobami LGBT w relację agoniczną, a wreszcie - zmian prawa).
\end{abstract}

Słowa kluczowe: relacje prawo-intymność, polityczność, Chantal Mouffe, prawa osób LGBT, art. 18 Konstytucji RP, hegemoniczny dyskurs prawoznawstwa 
I. Poszukiwanie zasad i utrzymywanie przez społeczeństwo instytucji, które w obliczu wprowadzonego przez polityczność konfliktu będą tworzyć porządek umożliwiający ludzkie współistnienie ${ }^{1}$, jest dziś pilną koniecznością. Podzielam tu — stojące w opozycji do hegemonicznej wizji liberalnej — tezy Chantal Mouffe: o nieusuwalności antagonizmu leżącego u podstaw życia społecznego oraz o tym, że problemy polityczne nie mają natury czysto technicznej i nie mogą być rozwiązywane wyłącznie przez ekspertów, lecz właściwie sformułowane wymagają dokonania wyboru pomiędzy zwalczającymi się alternatywami ${ }^{2}$. Dla prawników (ekspertów zajmujących się prawem) może to być wskazówka, że wiele problemów, na przykład dotyczących relacji prawo-intymność ${ }^{3}$, które bardzo często mają polityczny (antagonistyczny) charakter, nie może być rozwiązanych jedynie przez odwołanie się do tradycyjnych prawniczych kategorii, metod i paradygmatów. W obliczu politycznego problemu (odnoszącego się chociażby do relacji prawo-intymność) prawnik ekspert najczęściej powie, że „takie jest prawo”, a więc w taki (zgodny z prawem), a nie inny sposób dany problem został „rozwiązany”. Konserwowanie politycznych problemów za pomocą prawa nie służy jednakże ich rozwiązywaniu. Przykładowo powoływanie się przez większość doktryny i orzecznictwa na interpretację art. 18 Konstytucji RP, zgodnie z którą przepis ten nie tylko uniemożliwia instytucjonalizację na poziomie ustawowym w Polsce związków jednopłciowych czy też partnerskich $^{4}$, ale też uniemożliwia zarejestrowanie w Polsce małżeństwa zawartego za gra-

${ }^{1}$ Nawiązuję tu do pojęcia polityczności proponowanego przez Chantal Mouffe, która dokonuje następującego rozróżnienia: ,przez »polityczność« rozumiem wymiar antagonizmu leżący u podstaw każdego ludzkiego społeczeństwa, przez »politykę« natomiast zestaw praktyk i instytucji, które w obliczu wprowadzonego przez polityczność konfliktu tworzą porządek umożliwiający ludzkie współistnienie" - eadem, Polityczność. Przewodnik Krytyki Politycznej, przeł. J. Erbel, Warszawa 2008, s. 24.

2 Ibidem, s. 24-25. W wywiadzie opublikowanym 21 lutego 2015 roku na łamach „Krytyki Politycznej” Ch. Mouffe wskazuje: „Żywa polityka demokratyczna musi dawać ludziom możliwość dokonywania autentycznych wyborów. Demokratyczna polityka musi być stronnicza. Aby zaangażować się w politykę, obywatele muszą czuć, że chodzi w niej o prawdziwą alternatywę. Dzisiejsze niezadowolenie z partii demokratycznych bardzo źle wpływa na politykę demokratyczną. W wielu krajach doprowadziło do pojawienia się populistycznych partii prawicowych, przedstawiających się jako jedyne, które oferują alternatywę i które oddają głos ludziom zaniedbanym przez partie głównego nurtu" - Mouffe: Demokratyczna polityka musi być stronnicza, https://krytykapolityczna.pl/kraj/mouffe-demokratyczna-polityka-musi-byc-stronnicza/ (dostęp: 7.02.2020).

3 Szerzej na temat pojęcia relacji prawo-intymność piszę w pracy: P. Sut, Relacje prawo-intymność jako przedmiot prawniczej refleksji, Gdańsk 2019.

${ }^{4}$ W komentarzu do art. 18 Konstytucji wskazuje się: „Treścią art. 18 Konstytucji RP jest ustanowienie adresowanego do ustawodawcy zakazu rejestrowania związków faktycznych dwojga osób fizycznych (niezależnie od płci osób w nich pozostających) w sposób inny niż poprzez nadanie im charakteru małżeństwa. Te zaś zostało ograniczone jedynie do związków pomiędzy kobietami i mężczyznami [...]. Tak jak wskazywano powyżej, cechą instytucji małżeństwa jest to, że jest ono związkiem zarejestrowanym prawnie, a więc i podlegającym regulacji prawnej. Jest ono zarazem niezwykle szerokim ograniczeniem praw osób w nim pozostających. Związek tak szeroko ograniczający wolność samych 
nicą przez osoby tej samej płci ${ }^{5}$, a nawet że stanowi jedną z przeszkód transkrypcji zagranicznego aktu urodzenia dziecka, w którym jako rodzice wpisane są osoby tej samej płci ${ }^{6}$, prowadzi do wykluczenia osób nieheteronormatywnych oraz utrudnia

stron tego stosunku ma podstawę prawną w prawie polskim w art. 18 Konstytucji RP. W jego zaś świetle związkiem tym jest jedynie zarejestrowana relacja między kobietą i mężczyzną. [...] W świetle regulacji art. 18 Konstytucji RP takie rozwiązanie wydaje się być zresztą świadomym wyborem aksjologicznym w kontekście wymienienia po sobie małżeństwa i rodziny. W doktrynie zauważa się, że małżeństwo podlega ochronie, gdyż jest ono - po urodzeniu choć jednego dziecka — potencjalną podstawą rodziny, zaś związek osób tej samej płci, jako niemogący realizować funkcji prokreacyjnej, nie może być podstawą rodziny" cyt. za: Art. 18 Konstytucja RP red. Safjan/Bosek 2016, wyd. 1/Borysiak, [w:] Konstytucja RP, t. 1. Komentarz do art. 1-86, red. M. Safjan, L. Bosek, Warszawa 2016, Legalis; wszystkie wyróżnienia autora cytowanego komentarza.

5 Por. przykładowe tezy zawarte w uzasadnieniach wyroków sądów administracyjnych: wyrok Naczelnego Sądu Administracyjnego z dnia 28 lutego 2018 roku, II OSK 1112/16, Legalis nr 1740407: „W świetle prawa obowiązującego w Polsce małżeństwa jednopłciowe są niedopuszczalne, zatem zagraniczny akt małżeństwa może zostać przeniesiony do rejestru stanu cywilnego w drodze transkrypcji jedynie wówczas, gdy wskazuje jako małżonków mężczyznę i kobietę"; wyrok Wojewódzkiego Sądu Administracyjnego w Warszawie z dnia 25 stycznia 2019 roku, IV SA/Wa 2717/18, Legalis nr 1917097: „Zagraniczny dokument stanu cywilnego, jakim jest akt małżeństwa, może podlegać transkrypcji do polskiego rejestru stanu cywilnego tylko wtedy, gdy jako małżonków wskazuje kobietę i mężczyznę. W innym przypadku, gdy akt małżeństwa wymienia małżonków jednej płci (mężczyzn), transkrypcja jako sprzeczna z podstawowymi zasadami porządku prawnego RP jest niedopuszczalna, a wymóg wskazania we wzorze aktu jako małżonków kobiety i mężczyzny znajduje tym samym swoje uzasadnienie w przepisach obowiązujących ustaw"; wyrok Wojewódzkiego Sądu Administracyjnego w Warszawie z dnia 18 września 2019 roku, IV SA/Wa 1638/19, Legalis nr 2233676: „1. Transkrypcja aktu małżeństwa zawartego między osobami tej samej płci nie jest możliwa z uwagi na sprzeczność z podstawowymi zasadami porządku prawnego Rzeczypospolitej Polskiej (art. 107 pkt 3 ustawy z dnia 28 listopada 2014 r. Prawo o aktach stanu cywilnego w zw. $\mathrm{z}$ art. 18 Konstytucji RP w zw. z art. 1 KRO). 2. Tam gdzie prawo krajowe wskazuje na przesłankę trwałego wspólnego pożycia (oczywiście zarówno w odniesieniu do uprawnień, jak i do obowiązków), w świetle konstytucyjnej zasady równości (art. 32 Konstytucji) nie ma podstaw do różnicowania praw i obowiązków z uwagi na płeć czy orientację seksualną konkubentów. Natomiast instytucja małżeństwa, zgodnie z wolą wyrażoną w referendum konstytucyjnym przeprowadzonym zgodnie z regułami państwa demokratycznego, została przewidziana wyłącznie dla związku kobiety i mężczyzny (art. 18 Konstytucji RP). Zmiana tej podstawowej zasady konstytucyjnej może nastąpić wyłącznie w drodze zmiany Konstytucji RP (na co zwrócił uwagę m.in. TK w powołanym wyżej wyroku z 11 maja 2005 r.)".

6 W uzasadnieniu uchwały składu siedmiu sędziów NSA z dnia 2 grudnia 2019 roku, II OPS 1/19, Legalis nr 2256199, o treści: „Przepis art. 104 ust. 5 i art. 107 pkt 3 ustawy z dnia 28 listopada 2014 r. Prawo o aktach stanu cywilnego (Dz.U. 2014 r. poz. 1741, ze zm.) w związku z art. 7 ustawy z dnia 4 lutego 2011 r. Prawo prywatne międzynarodowe (Dz.U. z 2015 r. poz. 1792) nie dopuszcza transkrypcji zagranicznego aktu urodzenia dziecka, w którym jako rodzice wpisane są osoby tej samej płci” pośród szeregu argumentów znajduje się passus: „Zgodnie z art. 18 Konstytucji małżeństwo jako związek kobiety i mężczyzny, rodzina, macierzyństwo i rodzicielstwo znajdują się pod ochroną i opieką Rzeczypospolitej Polskiej. Zasady wynikające z Konstytucji znajdują odzwierciedlenie $\mathrm{w}$ przepisach rangi ustawowej. Ustawodawca nie przewidział $\mathrm{w}$ nich możliwości wpisania do polskiego aktu stanu cywilnego jako ojca osoby płci żeńskiej. Zgodnie z art. 60 pkt 4 p.PrASC akt urodzenia zawiera nazwiska, imiona oraz nazwiska rodowe, daty i miejsca urodzenia rodziców 
życie dzieciom wychowywanym przez pary jednopłciowe. Mamy tu zatem ,prawne" rozwiązanie politycznego problemu, które jednocześnie przybiera postać opresji. Jak sprawić, by owo prawne rozwiązanie politycznego problemu (regulowanego prawnie) nie prowadziło do opresji? Oczywiście prawnik ekspert może poprzestać na konstatacji (opierając się na jakimś hegemonicznym dyskursie prawoznawstwa), że „takie jest prawo”, na przykład że w ramach jakiegoś porządku prawnego małżeństwem może być wyłącznie związek kobiety i mężczyzny. Natomiast przyjmując nawet $\mathrm{w}$ uproszczeniu, że podstawową rolą naukowego prawoznawstwa jest egzegeza tekstów prawnych ${ }^{7}$, a także ocena obowiązującego prawa (oraz — jak uważam - krytyka prawa), podczas gdy rolą sądów - wymierzanie sprawiedliwości, stwierdzić należy, iż prawnik naukowiec i prawnik sędzia powinni działać ze świadomością ,pplityczności” wielu regulowanych prawnie problemów. A ponadto, że te regulowane prawnie polityczne problemy nie są jedynie problemami prawnym, lecz że mając właśnie charakter polityczny, wymagają spojrzenia wykraczającego poza tradycyjne prawnicze kategorie, metody i paradygmaty. Poszukiwanie rzeczywistych, a nie tylko „prawnych” rozwiązań rozmaitych politycznych problemów regulowanych prawnie skłaniać będzie do krytycznego spojrzenia na dotychczasowe (hegemoniczne) prawnicze dyskursy dotyczące tychże problemów oraz powinno prowadzić do kreowania przez prawoznawstwo i orzecznictwo alternatywnych dyskursów, które w przyszłości mogłyby przejąć pozycję hegemoniczną.

Nawiązuję tu do idei Mouffe, że zadaniem demokracji jest przekształcanie relacji antagonistycznych (relacji my-oni, których strony są wrogami niemającymi wspólnych punktów odniesienia) w relacje agoniczne (relacje my-oni, których strony są dla siebie nie wrogami, lecz „przeciwnikami” i mając świadomość niemożliwości zaistnienia racjonalnego rozwiązania dzielącego je konfliktu, uznają prawomocność swoich przeciwników $)^{8}$. W relacjach agonicznych wymiar antagonistyczny jest zawsze obecny, lecz będąc realną konfrontacją, rozgrywany jest według zaakceptowanych przez strony demokratycznych procedur ${ }^{9}$. Zdaniem Mouffe zamiast zgodnych z założeniami liberalizmu prób tworzenia instytucji, które za pomocą rzekomo bezstronnych procedur pojednałyby sprzeczne interesy i wartości, zadaniem teoretyków demokracji i polityków demokratycznych powinno być wyobrażenie sobie możliwości stworzenia „agonicznej” publicznej sfery sporu, w której mogłyby się konfrontować różne hegemoniczne projekty ${ }^{10}$.

dziecka. Rodzicami dziecka w prawie polskim mogą być tylko matka i ojciec. Polskie ustawodawstwo nie zna innej kategorii rodzica".

7 T. Pietrzykowski, Granice naturalizmu - granice nauk prawnych, [w:] Naturalizm prawniczy. Interpretacje, red. J. Stelmach et al., Warszawa 2015, s. 61.

8 Ch. Mouffe, op. cit., s. 35-36.

9 Ibidem, s. 36-37.

10 Ibidem, s. 18. 
Przykładowo współcześnie w Polsce konfrontacja między środowiskami konserwatywnymi a osobami LGBT $^{11} \mathrm{i}$ ich sojusznikami nie ma charakteru agonicznego, o czym świadczą chociażby wypowiedzi o „ideologii LGBT”, „tęczowej zarazie" oraz „strefy wolne od LGBT"12. Wątpliwe jest przy tym, w aktualnych warunkach politycznych, przeniesienie tego antagonizmu do agonicznej, publicznej sfery sporu, w której mógłby się rozegrać spór pomiędzy zwolennikami i przeciwnikami roszczeń osób LGBT. Myślę jednak, że pewną rolę do odegrania ma tu prawoznawstwo (i orzecznictwo sądowe), które - wciąż posługując się wspólnym uniwersum wartości, choć często różnie pojmowanych ${ }^{13}$, z zaprogramowaną przez edukację i praktykę prawniczą hegemoniczną, pozytywistyczną wizją prawa, jednak domagającą się, jak uważam, krytycznego podejścia - powinno wykonać wysiłek mający na celu skonfrontowanie różnych prawniczych dyskursów dotyczących praw osób LGBT. Jeżeli prawnicy wysuwaliby różne argumenty „za” i ,przeciw” tym roszczeniom, opierając się na jakichś uzgodnionych wartościach, takich jak na przykład wolność i równość, a te prawnicze dyskursy przenikałyby do sfery publicznej, to być może pozostali uczestnicy publicznego sporu dotyczącego owych roszczeń - idąc tym przykładem — zaczęliby traktować swoich adwersarzy jako przeciwników, a nie wrogów. Ewentualna utrata pozycji hegemonicznej przez obecnie w Polsce dominujący dyskurs prawniczy (odnoszący się w szczególności art. 18 Konstytucji RP) mogłaby w przyszłości doprowadzić do „ucywilizowania” publicznej konfrontacji dyskursów dotyczących roszczeń osób LGBT (i być może przekształcenia rejestrowanej aktualnie relacji antagonistycznej łączącej konserwatystów z osobami LGBT w relację agoniczną, a wreszcie - zmian prawa zgodnych $\mathrm{z}$ tendencjami obserwowanymi w krajach zachodnich).

II. W tekście poruszę jeszcze jeden wątek pozornie niezwiązany z kwestią związków współczesnej intymności, prawa i polityczności (w tym roszczeń osób LGBT i wielu innych politycznych problemów dotyczących relacji prawo-intymność). Wątek ten moim zdaniem wiąże się ze sferą zasad i instytucji, które w sytuacji antagonizmu tworzą porządek umożliwiający ludzkie współistnienie i dotyczy

11 W niniejszym tekście dla uproszczenia używam najpopularniejszej w publicznych dyskursach wersji skrótu określającego nieheteronormatywne i transgenderowe mniejszości — „LGBT”.

12 Por. informacja na stronie Rzecznika Praw Obywatelskich opublikowana w dniu 19 grudnia 2019 roku: Parlament Europejski potęia dyskryminację i mowę nienawiści wobec osób LGBTI w sferze publicznej, w tym polskie ,,strefy wolne of LGBTI”, https://www.rpo.gov.pl/pl/content/ parlament-europejski-potepia-dyskryminacje-i-mowe-nienawisci-wobec-osob-lgbti-w-sferze-publicznej (dostęp: 14.02.2020).

13 Jak pisze Ch. Mouffe: „Dla pewności, demokracja nie może przetrwać bez pewnej formy konsensusu, »konfliktowego konsensusu«, odnoszącego się do wierności wobec etyczno-politycznych wartości, konstytuujących zasady jego prawomocności oraz wobec instytucji, w które są one wpisane. Jednak musi także umożliwić dostępność różnych i czasem skonfliktowanych interpretacji tych współwyznawanych, etyczno-politycznych wartości, by obywatele mieli autentyczną możliwość wyboru pomiędzy prawdziwymi alternatywami” — eadem, Afekty demokracji, 3.05.2019, https://www.eurozine.com/afekty-demokracji/ (dostęp: 8.02.2020). 
rozgrywającego się w Polsce ( $\mathrm{z}$ różnym nasileniem od 2015 roku) sporu pomiędzy obozem politycznym obecnie (luty 2020 roku) sprawującym realną władzę w państwie a środowiskiem sędziowskim (oraz instytucjami Unii Europejskiej). Spór ten dotyczy przede wszystkim zasady niezależności sądów. Przywołany tu konflikt ma aktualnie charakter dynamiczny i nie będzie przeze mnie szerzej analizowany, lecz na bardzo ogólnym poziomie stanowić będzie egzemplifikację problemu niedostrzegania konieczności zawierania sojuszy w demokratycznej walce o wolność i równość ${ }^{14}$.

W doktrynie zasada niezależności jest uznawana za konstytutywną cechę sądów w ramach prawa do sądu (jako gwarancji praw podmiotowych jednostki) oraz wiązana z koncepcją państwa prawa, mającą być tejże niezależności polityczno-prawną podstawą ${ }^{15}$. Problem jednak w tym, że prawo do sądu - i to wcale nie ze względu na próby ograniczenia niezależności sądów — staje się coraz bardziej problematyczną gwarancją praw jednostek ${ }^{16}$, praktyka zaś prawno-ustrojowa w Polsce po 2015 roku jedynie dodatkowo obnażyła — w moim przekonaniu — niedostatki koncepcji państwa prawa ${ }^{17}$. Istotna jest tu jeszcze jedna (w istocie trywialna) konstatacja, że koncepcja państwa prawa oraz prawo do sądu bezsprzecznie są fundamentalnymi wartościami zachodniej kultury prawnej,

14 Ilustracją tego problemu są na przykład krytyczne opinie wyrażane przez uczestników tak zwanego Marszu Tysiąca Tóg wobec obecnych na tym marszu osób z tęczowymi flagami. W będącym reakcją na te zdarzenia liście otwartym z dnia 14 stycznia 2020 roku Kampania Przeciw Homofobii stwierdza między innymi: „W czasach zmasowanego ataku na osoby LGBT to wolne sądy stawiały odpór homofobicznej władzy zakazującej organizacji marszy równości. Tęczową flagą chcieliśmy dać sygnał środowisku prawniczemu, że teraz my stajemy po stronie praworządności, nie godząc się na zainicjowaną przez władze kampanię oszczerstw wobec sędziów. »Marsz się Pani pomylił«, »Nie o te wartości dzisiaj walczymy« usłyszały prawniczki, które na Marszu Tysiąca Tóg pojawiły się z tęczowymi flagami" - list otwarty KPH do organizatorów Marszu Tysiąca Tóg, https://kph.org.pl/list-marsz-tysiaca-tog/ (dostęp: 12.02.2020). W oświadczeniu z dnia 15 stycznia 2020 roku jeden z organizatorów Marszu Tysiąca Tóg ustosunkował się do listu KPH: „Chcemy podkreślić, że tak jak »nie ma wolności bez praworządności«, tak »nie ma praworządności bez solidarności«, zwłaszcza z osobami wykluczanymi i prześladowanymi. Stowarzyszenie Sędziów Themis jasno chce dać wyraz temu, że w przestrzeni publicznej nie ma miejsca na jakąkolwiek dyskryminację, w tym na zachowania homofobiczne, a widoczna różnorodność wśród obywateli, także na wydarzeniach organizowanych przez Stowarzyszenie Themis, stanowi siłę społeczeństwa, broniącego konstytucyjnych wartości" — oświadczenie Stowarzyszenia Sędziów Themis w związku z listem Stowarzyszenia Kampania Przeciwko Homofobii, http://themis-sedziowie.eu/aktualnosci/oswiadczenie-stowarzyszenia-sedziow-themis-w-zwiazku-z-listem-stowarzyszenia-kampania-przeciwko-homofobii/ (dostęp: 12.02.2020).

15 A. Machnikowska, O niezawistości sędziów i niezależności sąów w trudnych czasach. Wymiar sprawiedliwości w pułapce sprawności, Warszawa 2018, s. 33.

16 P. Sut, Kryzys gwarancyjnej roli prawa a prawoznawstwo, „Prawo” 312. Czy koniec teorii prawa? Z zagadnień teorii i filozofii prawa, red. P. Jabłoński, 2011, s. 214-217.

17 Gdy prawo będzie tworzone „z dnia na dzień”, bez realnej konstytucyjnej kontroli, bez konsultacji społecznych, lecz wyłącznie zgodnie z wolą kierowniczych ośrodków władzy państwowej, to zasada państwa prawa nie będzie spełniać swoich założonych funkcji. 
lecz są to wartości instrumentalne. W założeniu powinny one służyć realizacji społecznych i jednostkowych interesów, choć niektóre dominujące dyskursy prawnicze wydają się nadawać tym wartościom quasi-religijny, dogmatyczny charakter (metaforycznie: sędziowie odgrywają w tych dyskursach rolę kapłanów, a prawoznawcy — teologów). Jednocześnie coraz trudniej przekonać „wyznawców” (to jest społeczeństwo) do wiary w te wartości ${ }^{18}$. Być może jedną z przyczyn (zapewne nie jedyną) krytycznego społecznego nastawienia do sądownictwa w Polsce jest wieloletnie zaniechanie jego realnej reformy, która miałaby na względzie właśnie służebny charakter prawa do sądu.

Tu pojawia się nieoczywista, paradoksalna idea, że być może jedną (zapewne z wielu) dróg do odzyskania przez społeczeństwo utraconej wiary w państwo prawa i prawo do sądów mogłoby być prawne zapewnienie jednostkom realnej wolności i równości, na przykład w sferze relacji prawo-intymność. Przykładowo zapewnienie równości małżeńskiej przez instytucjonalizację nieheteronormatywnych małżeństw, a także na przykład równe traktowane sprawców przestępstw pedofilii samo w sobie nie rozwiąże trapiących sądownictwo problemów, takich jak coraz bardziej skomplikowane procedury, przewlekłość postępowań, zaskakujące rozstrzygnięcia zawarte w wyrokach itp. Gdyby jednak prawo w większym niż dotychczas stopniu wprowadzało nie pozorną, lecz realną wolność i równość, to być może prowadziłoby to do zmian społecznego nastawienia do zasad i instytucji umożliwiających współistnienie w warunkach konfliktu wprowadzonego przez polityczność. Jednocześnie wydaje się, że uwzględnienie w ramach tworzenia prawa i dyskursu prawniczego roszczeń mniejszości seksualnych (a także na przykład

18 Rzecznik Praw Obywatelskich Adam Bodnar w wystąpieniu wprowadzającym w dniu 14 stycznia 2019 roku na konferencji „Jak przywrócić państwo prawa?”, zorganizowanej przez Forum Idei Fundacji Batorego, stwierdził: „Mieliśmy wielkie problemy, i wciąż mamy: z przewlekłością postępowań sądowych oraz ogólnie z jakością działania sądów. Z tym, że nie zawsze działały mechanizmy odszkodowawcze w sytuacji niezgodnych z prawem działań organów państwa [...]. Dlatego główne pytanie to nie tylko pytanie o to, jak przywrócić państwo prawa, ale jak sprawić, aby to przywrócone państwo prawa faktycznie realizowało gwarancje konstytucyjne. Jest to zatem pytanie nie tylko o to jak, ale także dla kogo i po co? Czy prawa człowieka będą w pełni realizowane? Czy prawa pracownicze będą chronione? Czy wymiar sprawiedliwości będzie im służył? Jak spowodować, aby to odnowione państwo prawa realizowało w pełni wartości konstytucyjne wyrażone w naszej Konstytucji z 2 kwietnia 1997 r. Przykładem może być np. dyskusja na temat roli sądów w kontekście relacji z TS UE. Sądy stały się aktywnymi uczestnikami tych postępowań w obronie własnej niezależności. Jest cała seria pytań prejudycjalnych skierowanych do TS UE. Ale czy np. sądy w ciągu najbliższych miesięcy czy lat będą miały taką samą siłę, aby chronić prawa konsumentów, ochronę środowiska, prawo do obrony w sprawach karnych, czy inne różne kwestie, które wchodzą w zakres prawa europejskiego, a gdzie dotychczas trudno było szukać jakiejś specjalnej aktywności, jeśli chodzi o występowanie do TS UE?”-Jak sprawić, aby przywrócone państwo prawa realizowało gwarancje konstytucyjne? Ważne, by nie wpaść w spirale kolejnych zemst, https://www.rpo.gov.pl/pl/content/jak-sprawic-aby-przywrocone-panstwo-prawa-realizowalo-gwarancje-konstytucyjne (dostęp: 14.02.2020); wszystkie wyróżnienia autora wystąpienia. 
w obrębie stosowania prawa skuteczne rozliczenie problemu pedofilii w Kościele katolickim ${ }^{19}$ ) stało się co najmniej tak samo ważne dla rzeczywistej realizacji idei wolności i równości jak walka o „wolne” sądy czy o praworządność.

III. Jeśli jednak wskazuję tu wolność i równość jednostek jako cel prawnej regulacji, to nie chodzi mi o minimalistyczną, liberalną, na przykład berlinowską, wersję wolności „negatywnej” lub ideę równości rozumianej jako formalna równość wobec prawa ${ }^{20}$. Nie należy jednak kwestionować liberalizmu jako takiego, gdyż jak pisali przeszło trzydzieści lat temu Ernesto Laclau i — wspominana już wielokrotnie w niniejszym tekście — Chantal Mouffe w głośnej Hegemonii i socjalistycznej strategii: ,jako zasada etyczna chroniąca prawo jednostki do swobodnego urzeczywistnienia swych ludzkich możliwości jest on dzisiaj o wiele ważniejszy niż kiedykolwiek przedtem" ${ }^{21}$. Dla autorów tych demokracja liberalna jest punktem wyjścia realizacji idei wolności i równości, jednakże wymagającym zradykalizowania, w związku z czym pojawia się projekt „demokracji radykalnej" jako powiązania antysystemowych walk prowadzonych przez różne grupy społeczne, co ma przełamać panujący neoliberalny porządek i przyczynić się do zbudowania bardziej wolnego, demokratycznego i egalitarnego społeczeństwa ${ }^{22}$. Laclau i Mouffe posługują się tu pojęciem „demokratyczna równoważność”, która jest „hegemoniczna” w tym sensie, że ustanawia sojusz między danymi interesami, lecz także przekształca tożsamość sił wchodzących w skład tego sojuszu ${ }^{23}$ Piszą oni:

Aby obrona interesów robotników nie odbywała się kosztem praw kobiet, imigrantów ani konsumentów, należy ustanowić równoważność między tymi rozmaitymi walkami. Jedynie pod tym warunkiem walki przeciwko władzy mogą zyskać prawdziwie demokratyczny charakter, a domaganie się praw nie będzie się opierać na podejściu indywidualistycznym, lecz na poszanowaniu praw do równości przysługujących innym podporządkowanym grupom² ${ }^{24}$.

Wiele lat później Mouffe, komentując projekt „radykalnej i pluralistycznej demokracji”, wskazała:

Opowiadamy się za taką radykalizacją istniejących instytucji demokratycznych, by zasady wolności i równości stały się bardziej efektywne w coraz większej liczbie relacji społecznych.

19 W niniejszym tekście problem ten przywołuję wyłącznie jako egzemplifikację politycznego problemu regulowanego prawnie, którym nie będę się jednak szerzej zajmować.

${ }^{20}$ Tej zasadzie formalnej równości wobec prawa czasami w dyskursie politycznym, a czasem naukowym nadaje się paradoksalną treść (na przykład w Polsce panuje równość małżeńska, gdyż każdy, niezależnie od orientacji seksualnej, może zawrzeć związek małżeński, oczywiście pod warunkiem że jest to małżeństwo kobiety i mężczyzny).

${ }^{21}$ E. Laclau, C. Mouffe, Hegemonia i socjalistyczna strategia. Przyczynek do projektu radykalnej polityki demokratycznej, przeł. S. Królak, Wrocław 2007, s. 193.

${ }^{22}$ K. Morawski, Zamiast neoliberalnej hegemonii, „Nowa Krytyka” 2010, nr 24-25, s. 335336.

23 E. Laclau, Ch. Mouffe, op. cit., s. 193.

${ }^{24}$ Ibidem. 
Naszym celem, jak wskazałam wcześniej, było uwzględnienie żądań nowych ruchów społecznych. Według nas wyzwaniem dla lewicy było wynalezienie takiego sposobu artykulacji nowych żądań wysuwanych przez feministki, antyrasistów, ruchy gejowskie i ekologiczne, by połączyć ich żądania $\mathrm{z}$ tymi formułowanymi w kategoriach klasowych. Pod tym względem ważnym pojęciem w Hegemonii był „łańcuch ekwiwalencji”25.

Zgodnie z teorią dyskursu Laclau i Mouffe charakterystyczna dla demokracji liberalnej jest wolność słowa, w której obrębie toczy się rywalizacja o hegemonię nad wielością prowadzonych dyskursów i narzucenie własnego znaczenia danego stanu rzeczy (kluczowe znaczenie ma tu pojęcie „,antagonizmu”26, które już wcześniej przedstawiłem w ujęciu Mouffe). Tak więc poszczególne grupy rywalizują z sobą o prawo do narzucenia zarówno swojego dyskursu, jak i zasad, którymi społeczeństwo będzie się rządzić, antagonizmy zaś są i symbolicznymi, i dyskursywnymi konstrukcjami mającymi podłoże raczej psychologiczne niż społeczne (konflikty społeczne wybuchają, gdy aktorzy społeczni mają problemy z określeniem własnej tożsamości, która jest blokowana) ${ }^{27}$. Niewątpliwie we współczesnej Polsce o prawo do narzucenia swojego dyskursu i zasad, którymi społeczeństwo będzie się rządzić, rywalizują z sobą zwolennicy i „wrogowie” roszczeń osób LGBT.

IV. Seksualność i intymność odgrywają szczególną rolę w dzisiejszych dyskursach w Polsce, w tym w przybierającej różne nasilenie konfrontacji dyskursu „,ideologii LGBT”28, reprezentowanego i artykułowanego w naszym kraju przez

25 Mouffe: Demokratyczna...

${ }^{26}$ P. Przyłęcki, Założenia teorii dyskursu Ernesta Laclaua i Chantal Mouffe, „Przegląd Socjologiczny" 62, 2013, s. 17-18.

27 Ibidem, s. 12.

28 Oto kilka wypowiedzi, które można zaliczyć do tego dyskursu: „Jeżeli nie ma ideologii LGBT, to co robią na Marszach Równości ludzie, którzy nie należą do środowiska homoseksualnego czy transseksualnego? Dlaczego wpisują ich program w działalność swoich partii politycznych? Skąd bierze się rozdźwięk między programem głoszonym przez organizacje LGBT a postawą wielu homoseksualistów? - mówi portalowi wPolityce.pl ks. Henryk Zieliński" — Ks. Zieliński: „Jeżeli nie ma ideologii LGBT, to co robia na Marszach Równości ludzie, którzy nie należa do środowiska homoseksualnego?", 4.08.2019, https://wpolityce.pl/kosciol/457821-nasz-wywiad-ks-zielinski-istnieje-ideologia-lgbt (dostęp: 14.02.2020). O tym, jak „, kształtowała się ideologia LGBT, by przybrać dzisiejszą postać”, pisze Robert Tekieli. Autor ten, po krótkim scharakteryzowaniu działalności różnych osób zajmujących się na Zachodzie seksualnością (na przykład Alfreda Kinseya, Margaret Mead, Judith Butler), zadaje pytanie: „Czemu wyznawcy ideologii LGBT i sympatycy tego ruchu próbują ukryć istnienie ideologii i wmówić nam, że jej przeciwnicy nienawidzą lesbijek, gejów, biseksualistów oraz transwestytów, i chcą ich dyskryminować, a nawet eksterminować? Czemu kłamią? Kłamią, by ogłuszyć opinię publiczną zarzutem, że brak zgody na ideologię LGBT oznacza nieakceptowalną nienawiść do ludzi. Chcą z osób broniących swoich dzieci przed deprawacją, broniących Kościoła i instytucji tradycyjnej rodziny, zrobić potworów, by w końcu wyeliminować ich z życia publicznego. Wyrzucić z pracy jak pracownika Ikei, wsadzić do więzienia na ponad 6 lat, jak modlącą się jedynie przed klinikami aborcyjnymi Mary Wagner, a w końcu pozbawić praw publicznych i izolować" - [Tylko u nas] Robert Tekieli: Ideologia LGBT? Oczywiście, że istnieje. Oto dowody, 13.08.2019, https://www.tysol.pl/a35757--Tylko-u-nas-Rober- 
różne środowiska konserwatywne i Kościół katolicki, oraz dyskursu „praw osób LGBT" (oba dyskursy nazywam tak na potrzeby niniejszego tekstu), reprezentowanego i artykułowanego przez środowiska osób LGBT, ,progresywne” i lewicowe.

Dla pierwszej grupy seksualność jest papierkiem lakmusowym pozwalającym odróżnić „,normalność” i to, co jest zgodne z jakimś prawem natury, od tego, co nie jest normalne i naturalne. Z jakichś względów dyskurs „,ideologii LGBT” dokonuje diabolizacji środowiska LGBT, gdyż w jego ramach pojawiają się twierdzenia, że postulaty środowisk LGBT są zagrożeniem dla fundamentów cywilizacji, kultury, państwa, rodziny i dzieci.

Druga grupa podnosi, że osoby nieheteronormatywne wciąż muszą mierzyć się z wykluczeniem, gdyż nadal doznają różnych form dyskryminacji spowodowanej brakiem wiedzy i zrozumienia problemów osób LGBT, manifestowaną wrogością społeczną, polityczną i edukacyjną, marginalizowaniem osób LGBT, odmawianiem im podstawowych praw człowieka ${ }^{29}$.

Gdzieś pomiędzy tymi dwoma konfrontującymi się dyskursami ulokowane jest milczące, często obojętne centrum, które od czasu do czasu ewokuje głosami liberałów, że kwestie praw osób LGBT należy taktycznie wycofać z dyskursu publicznego, gdyż w pierwszej kolejności należy „załatwić” inne, ważniejszej sprawy, takie jak na przykład odsunięcie od władzy aktualnie rządzących ${ }^{30}$.

Mamy tu do czynienia - w nawiązaniu do Foucaultowskiej koncepcji dyskursu jako praktyki formującej przedmioty, ustanawiającej podmiotowość oraz stosunki władzy ${ }^{31}$ — ze swoistą grą dyskursów, rozumianą jako walka o uprawomocnienie pewnych wersji rzeczywistości (narracji) ${ }^{32}$. Przywołane dwie zasadnicze wersje

t-Tekieli-Ideologia-LGBT-Oczywiscie-ze-istnieje-Oto-dowody (dostęp: 14.02.2020). Natomiast na konferencji „Ideologia LGBT i gender. Doświadczenia państw UE i polityka UE” zorganizowanej na Uniwersytecie Papieskim Jana Pawła II w Krakowie ks. Paweł Bortkiewicz powiedział między innymi: „Musimy analizować pojęcia i musimy spoglądać na prawdę. Usłyszeliśmy tu od państwa, że LGBT nie jest ideologią. Jeden argument, który mówiłby o tym, że LGBT nie jest ideologią nie usłyszeliśmy go" - Ks. prof. Pawet Bortkiewicz: Ideolodzy LGBT myla prawa z roszczeniami, 9.12.2019, https://www.fronda.pl/a/ks-prof-pawel-bortkiewicz-ideolodzy-lgbt-myla-prawa-z-roszczeniami,137367.html (dostęp: 20.02.2020).

29 Por. „Uwagi wstępne” w publikacji Prawa osób LGBT w Polsce. Raport z badań nad wdrażaniem Zalecenia CM/Rec (2010)5 Komitetu Ministrów Rady Europy dla Państw Członkowskich w zakresie środków zwalczania dyskryminacji opartej na orientacji seksualnej lub tożsamości plciowej pod redakcja Zofii Jabłońskiej i Pawła Knut, Kampania Przeciw Homofobii, 2012, https://www. kph.org.pl/publikacje/prawa_osob_lgbt.pdf (dostęp: 14.02.2020).

30 Por. np. informację ze strony „Gazety Prawnej” z 8 maja 2017 roku: Schetyna: Poważna rozmowa o zwiazkach partnerskich - po nastepnych wyborach parlamentarnych, https://www.gazetaprawna.pl/artykuly/1040854,schetyna-zwiazki-partnerskie.html (dostęp: 14.02.2020).

31 Por. w szczególności tom 1: Wola wiedzy - M. Foucault, Historia seksualności, t. 1. Wola wiedzy, t. 2. Użytek z przyjemności, t. 3. Troska o siebie, przeł. B. Banasiak, T. Komendant, K. Matuszewski, Warszawa 1995.

32 M. Kwiecińska, Zmiana społeczna jako gra dyskursów, [w:] Nieobecne dyskursy, cz. 5, red. Z. Kwieciński, Toruń 1997, s. 217. 
rzeczywistości (dyskurs ,ideologii LGBT” i dyskurs „praw osób LGBT”) ostro rywalizują z sobą (dyskursy te dookreślają się też we wzajemnym odniesieniu do siebie - wykluczenie pewnych narracji definiuje dyskurs wykluczający ${ }^{33}$ ), a zwycięstwo jednego z nich będzie miało wpływ na kierunek zmian społecznych w Polsce, w tym zmian prawa — gdyż jak zauważa się w literaturze: ,dyskurs zajmujący w grze dominującą pozycję osiąga zarazem możliwość manipulacji mechanizmami marginalizacji innych dyskursów, a nawet ich całkowitego wykluczenia" ${ }^{34}$. U Davida Howartha pojawiają się ,»projekty hegemoniczne«, wiążące w całość różne wątki dyskursu i dążące do zdominowania (lub wytworzenia) struktury pola dostępnych znaczeń i, tym samym, do wytworzenia parametrów, w których będzie się formować tożsamość różnych przedmiotów i praktyk"35.

Wydaje się więc, że „odpuszczenie” przez liberalne centrum problemu praw osób LGBT nie daje nadziei, iż w jakimś „odpowiednim” momencie będzie można wrócić do tej kwestii. Realizacja praw mniejszości (nie tylko) seksualnych, nawet w wypadku demokratycznej zmiany reprezentacji parlamentarnej na bardziej liberalną, w warunkach kształtowania rzeczywistości społecznej przez hegemoniczny dyskurs ,ideologii LGBT”, może nie być zatem możliwa. Wracam w tym miejscu do idei konfrontowania prawniczych dyskursów dotyczących praw osób LGBT, gdyż być może ewentualna utrata pozycji hegemonicznej przez obecnie w Polsce dominujący dyskurs prawniczy dotyczący tych praw mogłaby w przyszłości doprowadzić do przekształcenia relacji antagonistycznej łączącej konserwatystów z osobami LGBT w relację agoniczną, a wreszcie - zmian prawa.

V. Przywołany już w niniejszym tekście art. 18 Konstytucji RP, w ujęciu aktualnie hegemonicznego dyskursu prawoznawstwa, jest moim zdaniem przykładem regulacji prawnej kreującej relację prawo-intymność jako relację władzy. Jak już wspomniałem, dyskurs ten głosi, że art. 18 uniemożliwia: instytucjonalizację związków jednopłciowych, zarejestrowanie w Polsce małżeństwa zawartego za granicą przez osoby tej samej płci, a nawet transkrypcję zagranicznego aktu urodzenia dziecka, w którym jako rodzice wpisane są osoby tej samej płci. Ten obecnie dominujący dyskurs prawoznawstwa o art. 18 prowadzi zresztą do wykreowania relacji prawo-intymność jako relacji władzy sprawowanej za pomocą prawa paradoksalnie nie tylko wobec nieheteronormatynwej mniejszości, ale też heteroseksualnej większości, która niekoniecznie praktykuje wzorcowy układ małżeński i rodzinny odkodowywany z art. 18.

Niejako w cieniu tego dominującego dyskursu pojawiają się odmienne interpretacje tego przepisu, głoszące między innymi, że art. 18, przyznając preferencyjną opiekę i ochronę małżeństwu jako związkowi kobiety i mężczyzny, nie wyklucza instytucjonalizacji innych modeli małżeństwa (o innej podmiotowej

\footnotetext{
33 Ibidem, s. 226.

34 Ibidem, s. 219.

35 D. Howarth, Dyskurs, przeł. A. Gąsior-Niemiec, Warszawa 2008, s. 159.
} 
strukturze), a tym bardziej związków partnerskich niebędących małżeństwem ${ }^{36}$, będące jednak wyraźnie w mniejszości.

Choć głosy na temat skutków prawnych tego przepisu są (bardzo nierówno) podzielone, to uważam, że przepis ten jest jednym z wielu przykładów regulacji prawnej prowadzącej do nieokreśloności prawa ${ }^{37}$. Nieokreśloności pojmowanej jako skutek regulacji, na której gruncie możliwy jest spór między stronami przedstawiającymi całkowicie odmienne, lecz „racjonalne” w ramach danej kultury prawnej argumenty na rzecz swoich przeciwstawnych tez (wszak w polskiej ustawie zasadniczej nie został wprost wyrażony zakaz instytucjonalizacji innych niż heteroseksualne małżeństwa związków, z treści zaś aktualnej regulacji konstytucyjnej zwolennicy i przeciwnicy instytucjonalizacji związków jednopłciowych wywodzą odmienne wnioski) ${ }^{38}$.

Ta nieokreśloność rodzi podejrzenie, że przywoływany tu hegemoniczny dyskurs prawoznawstwa (doktryny i orzecznictwa) przekonujący nas, że art. 18 stanowi między innymi konstytucyjną zaporę prawnej instytucjonalizacji innych niż małżeństwo kobiety i mężczyzny związków międzyludzkich mających komponent intymny, nie opiera się wyłącznie na jakichś „racjonalnych” argumentach prawnych, lecz (być może) na uprzedzeniach lub świadomie przyjętym albo nieuświadomionym założeniu, że wolą (celem) twórców Konstytucji było zakonserwowanie w tym zakresie stosunków społecznych i — co więcej — że „konserwacja" ta wciąż jest skuteczna ${ }^{39}$.

Jakie jednak miałyby być przyczyny zamiaru dokonania tej rzekomej konstytucyjnej konserwacji tradycyjnego układu małżeńskiego i rodzinnego? W tym zakresie istotne (historyczne) informacje na temat intencji twórców Konstytucji może przynieść analiza głosów w dyskusjach na posiedzeniach Komisji Konstytucyjnej Zgromadzenia Narodowego, a także analiza konserwatywnych, politycz-

${ }^{36}$ E. Łętowska, J. Woleński, Instytucjonalizacja zwiąków partnerskich a Konstytucja RP z 1997 r., Państwo i Prawo" 2013, nr 6, s. 23.

37 P. Sut, Relacje prawo-intymność „, ukryte” w Konstytucji Rzeczypospolitej Polskiej (problem instytucjonalizacji matżeństw homoseksualnych w Polsce wobec nieokreśloności prawa), „Filozofia Publiczna i Edukacja Demokratyczna” 7, 2018, nr 1, s. 236-246.

38 Ibidem, s. 236-237.

39 I to skuteczna mimo obserwowanych również w naszym kraju przemian intymności, mimo coraz donośniejszego artykułowania roszczeń przez osoby i środowiska LGBT, wreszcie — mimo zinstytucjonalizowania małżeństw jednopłciowych w większości krajów bliższego i dalszego nam Zachodu. Jak stwierdza Bolesław Banaszkiewicz: „W 1997 r. Zgromadzenie Narodowe i suweren w referendum potwierdzili, że intymne związki homoseksualne są sprawą ściśle prywatną, co zakłada ich ochronę przed bezprawnymi ingerencjami, ale wyklucza prawną instytucjonalizację. Obydwa rozstrzygnięcia to wizytówki rozumnego - tolerancyjnego, powściągliwego i niekoniunkturalnego — stosunku polskiego prawodawcy do problemów mniejszości seksualnych. Niezależnie od przedstawionych racji merytorycznych warto bronić tego modelu także przez szacunek dla demokracji oraz wzgląd na autorytet Konstytucji i potrzebę unikania nowych konfliktów ideologicznych w jej stosowaniu” — idem, ,Malżeństwo jako związek kobiety i mężczyzny”. O niektórych implikacjach art. 18 Konstytucji RP, „Kwartalnik Prawa Prywatnego” 22, 2013, nr 3, s. 655. 
no-religijnych dyskursów o projekcie art. 18. Jak zauważa Bolesław Banaszkiewicz, ostateczne brzmienie art. 18 obowiązującej Konstytucji pokazuje, jak dalece przepis ten uwzględnia wrażliwość właściwą opcji chrześcijańsko-demokratycznej ${ }^{40}$. Pojawia się tu więc kwestia prawnej regulacji seksualności motywowanej przesłankami pozaseksualnymi. Prawna regulacja seksualności (intymności) może być bowiem ujmowana jako historyczny proces zabiegania o równowagę między biologiczną warstwą popędu a przesłankami pozaseksualnymi, w tym ekonomicznymi i politycznymi ${ }^{41}$. Z jakiegoś też względu seksualność jest wyjątkowo podatnym elementem układu sprawowania władzy. Przecież Foucaultowska koncepcja władzy-wiedzy znajduje swoje najgłośniejsze odzwierciedlenie w pierwszym tomie Historii seksualności. Przykłady można mnożyć: dawniej religijna, a nieco później wczesnokapitalistyczna moralność seksualna w Europie była instrumentem sprawowania władzy nad społecznościami lub pewnymi grupami, na przykład kobietami czy klasami niższymi; dziś dyskurs diabolizujący osoby nieheteronormatywne może służyć zwieraniu szeregów zwolenników określonych sił politycznych.

Jednakże normatywizacja seksualności przechodzi na Zachodzie znamienną ewolucję. Co najmniej od schyłku XIX wieku, w ślad za koncepcjami Freuda, dzięki ruchom społecznym, politycznym i kulturowym, następuje zrzucanie jarzma władzy z seksualności ${ }^{42}$ oraz stopniowe redefiniowanie przesłanek ingerencji prawnej w sferę ludzkiej seksualności. Anthony Giddens aprobatywnie stwierdza, że współcześnie „seksualność” została odkryta, otwarta i jest dostępna różnym stylom życia ${ }^{43}$.

Obserwowane współcześnie, realne przecież, przemiany intymności niewątpliwie wpływają na jej prawną regulację. Przykładowo nie tak dawna penalizacja aktów homoseksualnych zostaje zastępowana na Zachodzie instytucjonalizacją nieheteronormatywnych małżeństw, dokonane zaś w drugiej połowie XX wieku oddzielenie prokreacji od seksu stanowiło między innymi krok w kierunku

${ }^{40}$ Ibidem, s. 645. Jak ponadto zauważa ten autor: „Trzeba przy tym pamiętać, że w wyniku dotkliwej porażki prawicy w wyborach parlamentarnych w 1993 r. lewicowo-centrowa koalicja konstytucyjna (SLD, PSL, UW i UP) dysponowała w Zgromadzeniu Narodowym większością wystarczającą do przegłosowania Konstytucji nawet wbrew prawicy. To, że w końcowym etapie prac Zgromadzenia Narodowego w pewnym zakresie większość wyszła naprzeciw postulatom prawicy, a także Kościoła katolickiego, wynikało z chęci osłabienia obaw znaczącego odłamu elektoratu, który wahał się, czy i jak głosować w referendum konstytucyjnym. Na posiedzenia KK [Komisji Konstytucyjnej — P.S.], na których rozpatrywano materie będące szczególnym przedmiotem zainteresowania Kościoła katolickiego, zapraszano osobę delegowaną przez Episkopat" - ibidem.

${ }^{41}$ K. Waszyńska, Seksualność człowieka w aspekcie historycznym, [w:] Przemiany seksualności w społeczeństwie współczesnym. Teoria i rzeczywistość, red. Z. Lew-Starowicz, K. Waszyńska, Poznań 2014, s. 65.

42 Ł. Dominiak, Problematyka seksualności w filozofii politycznej Michela Foucault, „Dialogi Polityczne" 2007, nr 8, s. 279.

43 A. Giddens, Przemiany intymności. Seksualność, miłość i erotyzm we wspótczesnych społeczeństwach, przeł. A. Szulżycka, Warszawa 2006, s. 27. 
rzeczywistego zrównania praw kobiet i mężczyzn. Jednocześnie prawo reguluje jednak wiele społecznych problemów związanych z intymnością, które wcześniej były niedostrzegane lub ukryte (takich jak na przykład przemoc seksualna, molestowanie i pedofilia $\left.{ }^{44}\right)$. Nie mam przy tym wątpliwości co do tego, że intymność i seksualność powinny podlegać prawnej regulacji (za feminizmem odrzucam liberalny postulat pozostawienia sfery seksualnej wyłącznie w domenie stosunków rodzinnych, małżeńskich i prywatności).

Czy jednak aktualnie relacje prawo-intymność przestają być relacjami rozprzestrzeniającymi opresyjną władzę? Krytyczne spojrzenie na prawnicze dyskursy dotyczące tych relacji pozwala na stwierdzenie, że treść współczesnego prawa, a co najmniej wiele jego regulacji, wciąż jest wyrazem dominacji jednych grup wobec innych (na przykład w niektórych krajach dominacji wizji małżeństwa i rodziny reprezentowanej przez większość społeczeństwa wobec postulatów mniejszości). Prawo „konserwuje” wiele tego typu konfliktów, odmawiając uznania emancypacyjnych dążeń określonych grup społecznych (chociażby kobiet i mniejszości seksualnych).

VI. Podsumowując dotychczasowe wywody, należy wskazać, że prawne rozstrzygnięcia dokonywane na podstawie interpretacji art. 18 Konstytucji RP, która jest przyjmowana przez aktualnie hegemoniczny dyskurs prawoznawstwa, prowadzą do opresji. Inspiruje to do krytycznego spojrzenia na tenże hegemoniczny dyskurs, a także do postulatu kreowania przez prawoznawstwo i orzecznictwo sądowe alternatywnych dyskursów w tym zakresie - uwzględniających rzeczywistą, a nie minimalistyczną lub formalną realizację wolności i równości — które w przyszłości mogłyby przejąć pozycję hegemoniczną.

Moim zdaniem zasadne będą próby kreowania tego typu alternatywnych dyskursów w obszarze rozważań dogmatycznoprawnych, na przykład opierając się na wykładni dynamicznej przepisów Konstytucji, a w szczególności art. 18, uwzględniającej przemiany współczesnej intymności, z jednoczesnym odrzuceniem statycznego podejścia zakładającego, że celem regulacji konstytucyjnej było zakonserwowanie przedmiotowych stosunków społecznych.

Interesująca wydaje mi się jednak przede wszystkim perspektywa rozważań o prawach osób LGBT, która wykracza poza dogmatycznoprawną refleksję. W nawiązaniu do idei „demokracji radykalnej” Laclau i Mouffe przyjmuję, że rzeczywista realizacja wolności i równości w społeczeństwie demokratycznym jest możliwa, gdy w jak największym stopniu uwzględnione zostaną słuszne roszczenia emancypacyjne rozmaitych grup dyskryminowanych, opresjonowanych czy mniejszości. Nie realizuje idei wolności i równości społeczeństwo przestrzegające równości płci, gwarantujące prawa kobiet, chroniące dzieci przed krzywdą, pedo-

${ }^{44}$ Niektóre z tych regulacji — z założenia słuszne przecież — poddane głęboko zakorzenionym w kulturze prawnej dyskursom, nie chronią jednak ofiar w odpowiedni sposób (przykładem jest tu karnistyczna koncepcja oporu ofiary przestępstwa zgwałcenia - szerzej na ten temat zob. P. Sut, Relacje prawo-intymność jako przedmiot..., s. 181-188). 
filią itp., a jednocześnie ignorujące prawa mniejszości seksualnych, narodowych czy rasowych. Oburzający jest zarówno obraz fizycznej przemocy stosowanej wobec kobiety, jak i obraz bitego, a może tylko wyśmiewanego przez szkolnych kolegów nastolatka homoseksualisty.

W recenzjach Hegemonii i socjalistycznej strategii Laclau i Mouffe pojawia się zarzut braku wyraźnego programu, który jako ewentualna siła hegemoniczna mógłby przyczynić się do zmiany panujących stosunków społecznych ${ }^{45}$. Kwestia sformułowania takiego programu nie jest oczywiście zadaniem prawoznawstwa. Rolą prawoznawstwa jest natomiast demistyfikacja konserwujących konflikty społeczne hegemonicznych prawniczych dyskursów, a następnie wyprowadzenie na pozycje hegemoniczne tych dyskursów, które będą umożliwiać rzeczywistą realizację wolności i równości.

\section{SOME REMARKS ON THE CONNECTIONS BETWEEN CONTEMPORARY INTIMACY, LAW AND POLITICAL (AGAINST THE HEGEMONIC DISCOURSE OF JURISPRUDENCE REGARDING ART. 18 OF THE POLISH CONSTITUTION OF 1997)}

\section{Summary}

Judgments issued based on the interpretation of art. 18 of the Polish Constitution, according to which this provision prevents institutionalization at the statutory level in Poland of same-sex relationships, and also prevents the registration in Poland of a marriage concluded abroad by persons of the same sex, and even that this provision constitutes one of the obstacles to transcription of a foreign birth certificate a child in which same-sex parents are entered as parents, lead to oppression. This inspires a critical look at this hegemonic discourse on jurisprudence regarding art. 18 of the Constitution, as well as to the demand for jurisprudence and judicial decisions to create alternative discourses in this respect - taking into account the actual, rather than minimalist or formal, implementation of freedom and equality - which in the future could take over the hegemonic position. The study includes a reference to the idea of Chantal Mouffe that the task of a democracy is to transform antagonistic relations (we/they, whose parties are enemies who do not have common points of reference) into agonic relations (we/they, whose parties are not enemies, and "opponents"). Undoubtedly, in Poland today, the confrontation between conservative circles and LGBT people and their allies is not agonizing and it is doubtful, in the current political conditions, to transfer this antagonism to the agonizing public sphere of the dispute. However, according to the author, jurisprudence (and jurisprudence) has a role to play here, which should make an effort to confront various legal discourses regarding LGBT rights. A possible loss of hegemonic position by the currently dominant legal discourse in Poland (in Article 18 of the Polish Constitution) could in the future lead to a "civilization" of public confrontation of discourses regarding claims of LGBT persons (and perhaps the transformation of the currently recorded antagonistic relationship linking conservatives with LGBT persons in an agonic relationship, and finally — changes in the law).

Keywords: relations between law and intimacy, political, Chantal Mouffe, LGBT rights, art. 18 of the Polish Constitution, hegemonic discourse on jurisprudence

45 K. Morawski, op. cit., s. 337. 


\section{BIBLIOGRAFIA}

Art. 18 Konstytucja RP red. Safjan/Bosek 2016, wyd. 1/Borysiak, [w:] Konstytucja RP, t. 1. Komentarz do art. 1-86, red. M. Safjan, L. Bosek, Warszawa 2016, Legalis.

Banaszkiewicz B., „Małżeństwo jako związek kobiety i mężczyzny”. O niektórych implikacjach art. 18 Konstytucji RP, „Kwartalnik Prawa Prywatnego” 22, 2013, nr 3.

Dominiak Ł., Problematyka seksualności w filozofi politycznej Michela Foucault, „Dialogi Polityczne" 2007, nr 8.

Foucault M., Historia seksualności, t. 1. Wola wiedzy, t. 2. Użytek z przyjemności, t. 3. Troska o siebie, przeł. B. Banasiak, T. Komendant, K. Matuszewski, Warszawa 1995.

Giddens A., Przemiany intymności. Seksualność, miłość i erotyzm we współczesnych społeczeństwach, przeł. A. Szulżycka, Warszawa 2006.

Howarth D., Dyskurs, przeł. A. Gąsior-Niemiec, Warszawa 2008.

Kwiecińska M., Zmiana społeczna jako gra dyskursów, [w:] Nieobecne dyskursy, cz. 5, red. Z. Kwieciński, Torun 1997.

Laclau E., Mouffe Ch., Hegemonia i socjalistyczna strategia. Przyczynek do projektu radykalnej polityki demokratycznej, przeł. S. Królak, Wrocław 2007.

Łętowska E., Woleński J., Instytucjonalizacja związków partnerskich a Konstytucja RP z 1997 r., „Państwo i Prawo” 2013, nr 6.

Machnikowska A., O niezawisłości sędziów i niezależności sądów w trudnych czasach. Wymiar sprawiedliwości w pułapce sprawności, Warszawa 2018.

Morawski K., Zamiast neoliberalnej hegemonii, „Nowa Krytyka” 2010, nr 24-25.

Mouffe Ch., Polityczność. Przewodnik Krytyki Politycznej, przeł. J. Erbel, Warszawa 2008.

Pietrzykowski T., Granice naturalizmu - granice nauk prawnych, [w:] Naturalizm prawniczy. Interpretacje, red. J. Stelmach et al., Warszawa 2015.

Przyłęcki P., Założenia teorii dyskursu Ernesta Laclaua i Chantal Mouffe, „Przegląd Socjologiczny” 62, 2013.

Sut P., Kryzys gwarancyjnej roli prawa a prawoznawstwo, „Prawo” 312. Czy koniec teorii prawa? Z zagadnień teorii i filozofii prawa, red. P. Jabłoński, 2011.

Sut P., Relacje prawo-intymność jako przedmiot prawniczej refleksji, Gdańsk 2019.

Sut P., Relacje prawo-intymność „,ukryte” w Konstytucji Rzeczypospolitej Polskiej (problem instytucjonalizacji matzeństw homoseksualnych w Polsce wobec nieokreśloności prawa), „Filozofia Publiczna i Edukacja Demokratyczna" 7, 2018, nr 1.

Waszyńska K., Seksualność czlowieka w aspekcie historycznym, [w:] Przemiany seksualności w spoteczeństwie wspótczesnym. Teoria i rzeczywistość, red. Z. Lew-Starowicz, K. Waszyńska, Poznań 2014.

\section{ŹRÓDŁA INTERNETOWE}

Ks. prof. Pawet Bortkiewicz: Ideolodzy LGBT myla prawa z roszczeniami, 9.12.2019, https://www. fronda.pl/a/ks-prof-pawel-bortkiewicz-ideolodzy-lgbt-myla-prawa-z-roszczeniami,137367. html (dostęp: 20.02.2020).

Ks. Zieliński: , ,Jeżeli nie ma ideologii LGBT, to co robia na Marszach Równości ludzie, którzy nie należa do środowiska homoseksualnego?”, 4.08.2019, https://wpolityce.pl/kosciol/457821-nasz-wywiad-ks-zielinski-istnieje-ideologia-lgbt (dostęp: 14.02.2020).

List otwarty Kampanii Przeciw Homofobii do organizatorów Marszu Tysiąca Tóg, https://kph.org. pl/list-marsz-tysiaca-tog/ (dostęp: 12.02.2020).

Mouffe Ch., Afekty demokracji, 3.05.2019, https://www.eurozine.com/afekty-demokracji/ (dostęp: 8.02.2020). 
Mouffe: Demokratyczna polityka musi być stronnicza", https://krytykapolityczna.pl/kraj/mouffe-demokratyczna-polityka-musi-byc-stronnicza/ (dostęp: 7.02.2020).

OświadczenieStowarzyszeniaSędziów ThemiswzwiązkuzlistemStowarzyszeniaKampaniaPrzeciwko Homofobii, http://themis-sedziowie.eu/aktualnosci/oswiadczenie-stowarzyszenia-sedziow-themis-w-zwiazku-z-listem-stowarzyszenia-kampania-przeciwko-homofobii/ (dostęp: 12.02.2020).

Parlament Europejski potępia dyskryminację i mowę nienawiści wobec osób LGBTI w sferze publicznej, w tym polskie , strefy wolne of LGBTI”, https://www.rpo.gov.pl/pl/content/parlament-europejski-potepia-dyskryminacje-i-mowe-nienawisci-wobec-osob-lgbti-w-sferze-publicznej (dostęp: 14.02.2020).

Prawa osób LGBT w Polsce. Raport z badań nad wdrażaniem Zalecenia CM/Rec (2010)5 Komitetu Ministrów Rady Europy dla Państw Członkowskich w zakresie środków zwalczania dyskryminacji opartej na orientacji seksualnej lub tożsamości płciowej pod redakcja Zofii Jabłońskiej i Pawła Knut, Kampania Przeciw Homofobii, 2012, https://www.kph.org.pl/publikacje/prawa_osob_lgbt.pdf (dostęp: 14.02.2020).

Schetyna: Poważna rozmowa o zwiazkach partnerskich — po następnych wyborach parlamentarnych, https://www.gazetaprawna.pl/artykuly/1040854,schetyna-zwiazki-partnerskie.html (dostęp: 14.02.2020).

[Tylko u nas] Robert Tekieli: Ideologia LGBT? Oczywiście, że istnieje. Oto dowody, 13.08.2019, https://www.tysol.pl/a35757--Tylko-u-nas-Robert-Tekieli-Ideologia-LGBT-Oczywiscie-ze-istnieje-Oto-dowody (dostęp: 14.02.2020).

Wystąpienie Rzecznika Praw Obywatelskich Adama Bodnara z dnia 14 stycznia 2019 roku na konferencji „Jak przywrócić państwo prawa?”, zorganizowanej przez Forum Idei Fundacji Batorego, Jak sprawić, aby przywrócone państwo prawa realizowało gwarancje konstytucyjne? Ważne, by nie wpaść w spiralę kolejnych zemst, https://www.rpo.gov.p1/p1/content/jak-sprawic-aby-przywrocone-panstwo-prawa-realizowalo-gwarancje-konstytucyjne (dostęp: 14.02.2020). 